\title{
Immunosenescence - the role in the immunotherapy of older population
}

\author{
Prcina $\mathrm{M}^{1}$, Novak $\mathrm{M}^{1}$, Cigankova $\mathrm{V}^{2}$, Kontsekova $\mathrm{E}^{1}$ \\ Institute of Neuroimmunology, Slovak Academy of Sciences, Bratislava, Slovakia. michal.prcina@savba.sk
}

\begin{abstract}
With ageing of their populations, many societies are challenged with serious systemic diseases. One of the causes of these diseases could be the age-related defects in immune system termed immunosenescence. Immunosenescence is characterized by accumulation of memory and non-functional immune cells, impaired signalling due to restricted repertoire of receptors, overall pro-inflammatory environment and complete dysregulation of the immune system. Consequences of immunosenescence are serious, older people are not able to respond to new stimuli, including infections and vaccinations and are more prone to oncologic, neurodegenerative and autoimmune diseases (Ref. 49). Text in PDF www.elis.sk.

KEY WORDS: immunosenescence, vaccination, neurodegeneration.
\end{abstract}

\section{Immunosenescence and its hallmarks}

Immunosenescence is a process during which the functions of the immune system decline with age. The consequences of immunosenescence are serious- elderly people are not able to respond properly to new infections and the balance between production of pro- and anti-inflammatory cytokines is shifted to pro-inflammatory phenotype. Aged immune cells are producers of a large number of specific factors, including proteases (metalloproteases MMP-1, 3, 10), chemokines (C-X-C motif chemokine ligand 1CXCL1, IL-8, C-C motif chemokine ligand 2- CCL2), cytokines (IL-1, IL-6, IL-7) and many others (1). On one hand these factors can activate the cellular immunity (2), but on the other hand, the presence of these factors leads to functional changes in surrounding tissues caused by increased autoimmune reactions and induces the systemic pro-inflammatory or even hyper-inflammatory phenotype which is associated with high mortality risk $(3,4)$.

The causes of immunosenescence are multiple and not completely understood. The problem is that immunosenescence affects the immune system on every level and both, innate and acquired immunity. The T-cell compartment exhibits consistent and pronounced age-related changes. These include thymus involution and decreased production of naive T cells (CD45RA + CD62L+, $\mathrm{CD} 95+$ ) in the periphery (5), loss of costimulatory protein CD28

${ }^{1}$ Institute of Neuroimmunology, Slovak Academy of Sciences, Bratislava, Slovakia, and ${ }^{2}$ The University of Veterinary Medicine and Pharmacy in Kosice, Slovakia

Address for correspondence: $\mathrm{M}$. Prčina, $\mathrm{RND}, \mathrm{PhD}$, Institute of Neuroimmunology of SAS, Dubravska cesta 9, SK-845 10 Bratislava, Slovakia. Phone: +421.2.54788100, Fax: +421.2 .54774276$

Acknowledgement: The work of the authors is supported by grant VEGA 2/0150/16 and EU structural fund ITMS 26240220008. and differentiation to effector phenotype. Moreover, diminished responsiveness to TCR signalling culminates in blunted T-cell proliferation, reduced IL-2 production and effector T-cell differentiation, lowering or inversion of CD4: CD8 T-cell ratios, reduction in naive and increase in memory cells, telomere shortening, and Tcell receptor (TCR) repertoire reduction (6). Additionally, analysis of the sera from elderly showed elevated C-reactive protein and transthyretin (7). It was shown that the occurrence of T-cell clonal expansions (TCE) in mice and humans is an age-dependent phenomenon, associated with dramatic losses in the TCR repertoire. Consistent with all of the above changes, there is some evidence that impaired CD8 response to virus infections in mice may partially correlate with age-related TCR repertoire loss $(8,9)$. Some studies showed that upregulation of several cytokines (i.e. TNF- $\alpha$ ) induced CD28 downregulation $(10,11)$. It seems that CD28-cells occur in pro-inflammatory environment and in turn, they produce more pro-inflammatory cytokines and thus they support the development of pro-inflammatory phenotype in elderly. Other studies pointed to the changes in number of $\mathrm{CD} 4+\mathrm{CD} 25+$ regulatory $\mathrm{T}$ cells, which are elevated in older age, but their suppressive activity to cytotoxic T cells and NK cells is decreased $(12,13,14)$.

However, T cells are not the only ones affected by immunosenescence. Changes on B cells (CD3-CD19+) and NK cells (CD3$\mathrm{CD} 16+\mathrm{CD} 56+)$ were recorded as well. In ageing population of NK cells, upregulation of CD57 was detected and thus CD57 was defined as a marker for maturation of NK cells and for cytotoxicity $(15,16,17,18)$. Changes in the expression of CD57 during ageing are prominent on cytotoxic T cells and thus CD57 was recognized as a marker of immune senescence (19). Several studies showed that under conditions of long-term stimulation, cytotoxic $\mathrm{T}$ cells change their phenotype from CD28+CD57- to CD28-CD57+ (20). These CD57+ cells show basic characteristics of senescence such as short telomeres, low telomerase activity, low expression 


\section{$217-220$}

of cell-cycle associated genes and a limited proliferative capacity $(20 ; 15)$. The cells were able to proliferate in a specific cytokine environment, were highly cytotoxic $(21,22)$, they expressed NK receptors and thus acquired NK-like phenotype $(17,18)$, but their apoptotic properties were questioned $(16,23)$.

The production of naive $\mathrm{B}$ cells declines with age and memory B cells and plasma cells of limited specificities accumulate, which contributes to the decrease in the capacity to respond to new antigens $(24,25,26,27,28)$. Age-related changes in the bone marrow, including the accumulation of fat deposits, are associated with the potential loss of specialized survival niches and a decrease in the number of B-cell progenitors. Although aged organisms have normal numbers of B cells in the periphery, they manifest several changes in their antibody repertoire, including a shift in antibody production from $\operatorname{IgG}$ to $\operatorname{IgM}$, from high affinity to low affinity, and from specificity for foreign antigens to specificity for self-antigens $(24,25)$.

Functional changes associated with increasing age are also present on dendritic cells and monocytes. Data are not complete for this part of immune system yet, but it seems that aged antigen presenting cells have impaired endocytosis and chemotaxis, downregulated expression of costimulatory molecules (CD86), decreased ability to present an antigen and lowered production of IL-12, which is important for T cells proliferation $(29,30,31)$.

\section{Neurodegeneration and the immune system}

Alzheimer's disease is a complex disorder characterized by the presence of amyloid plaques and neurofibrilary tangles in brain and the formation of these pathological hallmarks is driven by different mechanisms. Amyloid beta and pathological tau proteins seriously affect the state of the immune system in the brain and in the periphery. In order to reveal the molecular underpinnings of the interaction of pathologically modified tau proteins and the immune system, it is necessary to use transgenic models of neurofibrillary pathology with precisely staged and predictable progression of neurofibrillary pathology.

There is a massive over-activation of the immune cells in neurodegenerative disorders, like Alzheimer's disease (AD), which results in neuroinflammation. Over-activated microglia form clusters around amyloid plaques, which are one of the main pathological hallmarks of Alzheimer's disease (32). In vitro studies showed that microglia can phagocytize amyloid beta, but they are not able to degrade it $(33,34)$. Other results showed that not only amyloid beta, but also pathologically modified tau protein is a cause of neuroinflammation in Alzheimer's disease affected brain. Expression of a pathological form of tau protein in animal models leads to a prominent activation of microglia and astrocytes and to infiltration of leukocytes (mainly monocytes and dendritic cells) from periphery to the site of pathology $(35,36)$.

Moreover, the nature of immune response in the brain is heavily affected by the genetic background of the transgenic animals (36) and thus it can be supposed that the genetic factors can influence the nature of the immune response in Alzheimer's disease patients. Prominent differences were identified in the individual components of the peripheral immune system of $\mathrm{AD}$ patients. The major changes included altered distribution and activity of lymphocytes and macrophages, the presence of autoantibodies and abnormal cytokine production or even elevated numbers of $\mathrm{T}$ cells in the brains of the patients (37). Other studies showed lowered numbers of $\mathrm{T}$ and $\mathrm{B}$ cells in blood of $\mathrm{AD}$ patients, although the numbers of NK cells remained unaltered (38). Additionally, differences were described in cell counts in individual subpopulations of T cells. The numbers of cytotoxic T cells were lower and the numbers of helper T cells were higher in $\operatorname{AD}$ patients $(38,39)$. However, there was no correlation between the cognitive decline and $\mathrm{T}$ cell profile (38). Another study, which involved larger group of $\mathrm{AD}$ patients with various degrees of neurodegeneration, showed significant reduction of B cell numbers (40). On the other hand, there were no differences in the total numbers of T cells and NK cells, only specific subpopulations of cytotoxic T cells expressing CD71 and CD28 were elevated. All these changes in lymphocytes distribution and the selective elevation of some subpopulations of $\mathrm{T}$ cells in $\mathrm{AD}$ patients suggest that $\mathrm{AD}$ neurodegeneration processes have significant impact on the peripheral immune system. In vitro studies of monocytes and macrophages isolated from blood of AD patients showed a prominent pro-inflammatory phenotype and the cells produced much higher amounts of pro-inflammatory cytokines compared to cells from healthy controls (41). On the other hand, these cells are less effective in phagocytosis of amyloid-beta and showed limited potential for differentiation to macrophage phenotype (42).

\section{Vaccination and immunosenescence in neurodegeneration}

Immunosenescence is generally associated with higher risk of osteoporosis, Alzheimer's disease, cancers and various autoimmune disorders (43). Immunosenescence is a serious problem for public health, since elderly are on one hand more prone to common infections, but on the other most of them are not able to respond properly to common vaccinations. Only $17-53 \%$ of elderly can produce specific antibodies in response to vaccination, in contrast to $70-90 \%$ of young adults (44). Insufficient immune response is most prominently found in influenza vaccination programs but can heavily affect the development of other vaccines intended for elderly, such as vaccines against Alzheimer's disease. Current data suggest that the low response to vaccination against influenza is associated with expansion of cytotoxic T cells without expression of CD28 costimulatory molecule $(45,46,47)$. A similar situation was found in HIV patients, which exhibit high percentage of cytotoxic T cells without CD28 marker and with shortened telomeres.

In a study dealing with the clinical trial of the vaccine against Alzheimer's disease, it was showed that the titres of vaccine-specific antibodies strongly correlate with the relative numbers of $\mathrm{T}$ lymphocytes, especially $\mathrm{T}_{\mathrm{h}}$ lymphocytes (48). The vaccine was able to induce antibody immune response and interfere with the progress of the disease despite the neurodegenerative changes in the brains of the experimental animals (49). The question still remains, in what stage of neurodegeneration immune system fails in recognition of the new stimuli and protection against the disease. 
All these data suggest that the identification of new, reliable $\mathrm{T}$ - and B-cell markers of immunosenescence and neurodegeneration can bring in a new insight into the ageing immune system affected by neurodegeneration (e.g. Alzheimer's disease) and can help to predict the responsiveness of the immune system to new therapeutic antigens.

\section{Conclusion}

Immunosenescence is becoming one of the civilisation diseases, interfering with all the biggest problems in current medicine. From the scientific point of view, the causes and mechanisms of immunosenescence are mostly unknown. The papers published on the topic are rather descriptive, focusing on individual markers or individual pathways. For better understanding of the immune system and immunosenescence, more holistic approach and new multi-parameter methods combined with bioinformatics will be needed. This could be the way to fight new infections, to design potent vaccination programs for elderly and to develop new therapeutic vaccines that are effective at any age.

\section{References}

1. Freund A, Orjalo AV, Desprez PY, Campisi J. Inflammatory networks during cellular senescence: causes and consequences. Trends Mol Med 2010; 16 (5): 238-246.

2. Hoare M, Narita M. Transmitting senescence to the cell neighbourhood. Nature Cell Biol 2013; 15: 887-889.

3. Franceschi C, Bonafè M, Valensin S, Olivieri F, De Luca M, Ottaviani E, De Benedictis G. Inflamm-aging. An evolutionary perspective on immunosenescence. Ann N Y Acad Sci 2000; 908: 244-254.

4. Gomez CR, Boehmer ED, Kovacs EJ. The aging innate immune system. Curr Opin Immunol 2005; 17 (5): 447-462.

5. Aspinall R, Carroll J, Jiang S. Age-related changes in the absolute number of CD95 positive cells in T cell subsets in the blood. Exp Gerontol 1998; 33: 581-591.

6. Goronzy JJ, Lee WW, Weyand CM. Aging and T-cell diversity. Exp Gerontol 2007; 42: 400-406.

7. Wikby A, Ferguson F, Forsey R, Thompson J, Strindhall J, Löfgren S, Nilsson BO, Ernerudh J, Pawelec G, Johansson B. An immune risk phenotype, cognitive impairment, and survival in very late life: impact of allostatic load in Swedish octogenarian and nonagenarian humans. J Gerontol A Biol Sci Med Sci 2005; 60: 556-565.

8. Monteiro J, Batliwalla F, Ostrer H, Gregersen PK. Shortened telomeres in clonally expanded CD28-CD8+ T cells imply a replicative history that is distinct from their CD28+CD8+ counterparts. J Immunol 1996; 156: $3587-3590$.

9. Cicin-Sain L, Smyk-Pearson S, Currier N, Byrd L, Koudelka C, Robinson T, Swarbrick G, Tackitt S, Legasse A, Fischer M, NikolichZugich D, Park B, Hobbs T, Doane CJ, Mori M, Axthelm MK, Lewinsohn DA, Nikolich-Zugich J. Loss of naive T cells and repertoire constriction predict poor response to vaccination in old primates. J Immunol 2010; 184: 6739-6745.

10. Bryl E, Vallejo AN, Weyand CM, Goronzy JJ. Down-regulation of CD28 expression by TNF-alpha. J Immunol 2001; 167: 3231-3238.
11. Borthwick NJ, Lowdell M, Salmon M, Akbar AN. Loss of CD28 expression on CD8 (+) T cells is induced by IL-2 receptor gamma chain signaling cytokines and type I IFN, and increases susceptibility to activation-induced apoptosis. Int Immunol 2000; 12: 1005-1013.

12. Tsaknaridis L, Spencer L, Culbertson N, Hicks K, LaTocha D, Chou YK, Whitham RH, Bakke A, Jones RE, Offner H, Bourdette DN, Vandenbark AA. Functional assay for human CD4+CD25+ Treg cells reveals an age-dependent loss of suppressive activity. J Neurosci Res 2003; 74: 296-308.

13. Gregg R, Smith CM, Clark FJ, Dunnion D, Khan N, Chakraverty R, Nayak L, Moss PA.The number of human peripheral blood CD4+ CD25high regulatory T cells increases with age. Clin Exp Immunol 2005; 140: $540-546$.

14. Wang L, Xie Y, Zhu LJ, Chang TT, Mao YQ, Li J. An association between immunosenescence and CD4 $(+) \mathrm{CD} 25(+)$ regulatory T cells: a systematic review. Biomed Environ Sci 2010; 23: 327-332.

15. Focosi D, Bestagno M, Burrone O, Petrini M. CD57+ T lymphocytes and functional immune deficiency. J Leukoc Biol 2010; 87 (1): 107-116.

16. Brenchley JM, Karandikar NJ, Betts MR, Ambrozak DR, Hill BJ, Crotty LE, Casazza JP, Kuruppu J, Migueles SA, Connors M, Roederer M, Douek DC, Koup RA. Expression of CD57 defines replicative senescence and antigen-induced apoptotic death of $\mathrm{CD} 8+\mathrm{T}$ cells. Blood 2003; 101 (7): 2711-2720.

17. Vivier E, Anfossi N. Inhibitory NK-cell receptors on T cells: witness of the past, actors of the future. Nat Rev Immunol 2004; 4 (3): 190-198.

18. Nielsen CM, White MJ, Goodier MR, Riley EM. Functional Significance of CD57 Expression on Human NK Cells and Relevance to Disease. Front Immunol 2013; 4: 422.

19. Sze DM, Giesajtis G, Brown RD, Raitakari M, Gibson J, Ho J, Baxter AG, Fazekas de St Groth B, Basten A, Joshua DE. Clonal cytotoxic $\mathrm{T}$ cells are expanded in myeloma and reside in the CD8 (+)CD57 (+)CD28 (-) compartment. Blood 2001; 98 (9): 2817-2827.

20. Vallejo AN. CD28 extinction in human T cells: altered functions and the program of T-cell senescence. Immunol Rev 2005; 205: 158-169.

21. Pedroza-Seres M, Linares M, Voorduin S, Enrique RR, Lascurain R, Garfias Y, Jimenez-Martinez MC. Pars planitis is associated with an increased frequency of effector-memory CD57+ T cells. Br J Ophthalmol 2007; 91 (10): 1393-1398.

22. Chattopadhyay PK, BettsMR, Price DA, GostickE, HortonH, Roederer M, De Rosa SC. The cytolytic enzymes granyzme A, granzyme B, and perforin: expression patterns, cell distribution, and their relationship to cell maturity and bright CD57 expression. J Leukoc Biol 2009; 85 (1): 88-97.

23. Wood KL, Twigg HL 3rd, Doseff AI. Dysregulation of CD8+ lymphocyte apoptosis, chronic disease, and immune regulation. Front Biosci 2009; 14: 3771-3781.

24. Frasca D, Diaz A, Romero M, Landin AM, Blomberg BB. Age effects on B cells and humoral immunity in humans. Ageing Res Rev 2011; 10 (3): 330-335.

25. Frasca D, Landin AM, Lechner SC, Ryan JG, Schwartz R, Riley RL, Blomberg BB. Aging down-regulates the transcription factor E2A, activation-induced cytidine deaminase, and Ig class switch in human B cells. J Immunol 2008; 180 (8): 5283-5290.

26. Shi Y, Yamazaki T, Okubo Y, Uehara Y, Sugane K, Agematsu K. Regulation of aged humoral immune defense against pneumococcal bacteria by IgM memory B cell. J Immunol 2005; 175 (5): 3262-3267. 


\section{$217-220$}

27. Ademokun A, Wu YC, Dunn-Walters D. The ageing B cell population: composition and function. Biogerontology 2010; 11: 125-137.

28. Paganelli R, Quinti I, Fagiolo U, Cossarizza A, Ortolani C, Guerra E, Sansoni P, Pucillo LP, Scala E, Cozzi E, Bertollo L, Monti D, Franceschi C. Changes in circulating B cells and immunoglobulin classes and subclasses in a healthy aged population. Clin Exp Immunol 1992; 90 (2): 351-354.

29. Uyemura K, Castle SC, Makinodan T. The frail elderly: role of dendritic cells in the susceptibility of infection. Mech Ageing Dev 2002; 123 (8): 955-962.

30. Della Bella S, Bierti L, Presicce P,Arienti R, Valenti M, Saresella M, Vergani C, Villa ML. Peripheral blood dendritic cells and monocytes are differently regulated in the elderly. Clin Immunol 2007; 122 (2): 220-228.

31. Agrawal A, Gupta S. Impact of aging on dendritic cell functions in humans. Ageing Res Rev 2011; 10 (3): 336-345.

32. McGeer PL, Itagaki S, Tago H, McGeer EG. Reactive microglia in patients with senile dementia of the Alzheimer type are positive for the histocompatibility glycoprotein HLA-DR. Neurosci Lett 1987; 79 (1-2): 195-200.

33. Ard MD, Cole GM, Wei J, Mehrle AP, Fratkin JD. Scavenging of Alzheimer's amyloid beta-protein by microglia in culture. J Neurosci Res 1996; 43 (2): 190-202.

34. Paresce DM, Chung H, Maxfield FR. Slow degradation of aggregates of the Alzheimer's disease amyloid beta-protein by microglial cells. J Biol Chem 1997; 272 (46): 29390-29397.

35. Zilka N, Stozicka Z, Kovac A, Pilipcinec E, Bugos O, Novak M. Human misfolded truncated tau protein promotes activation of microglia and leukocyte infiltration in the transgenic rat model of tauopathy. J Neuroimmunol 2009; 209 (1-2): 16-25.

36. Stozicka Z, Zilka N, Novak P, Kovacech B, Bugos O, Novak M. Genetic background modifies neurodegeneration and neuroinflammation driven by misfolded human tau protein in rat model of tauopathy: implication for immunomodulatory approach to Alzheimer's disease. J Neuroinflammation 2010; 7: 64.

37. Rogers J, Luber-Narod J, Styren SD, Civin WH. Expression of immune system-associated antigens by cells of the human central nervous system: relationship to the pathology of Alzheimer's disease. Neurobiol Aging 1988; 9 (4): 339-349.

38. Richartz-Salzburger E, Batra A, Stransky E, Laske C, Köhler N, Bartels M, Buchkremer G, Schott K. Altered lymphocyte distribution in Alzheimer's disease. J Psychiatr Res 2007; 41 (1-2): 174-178.

39. Lombardi VR, García M, Rey L, Cacabelos R. Characterization of cytokine production, screening of lymphocyte subset patterns and in vitro apoptosis in healthy and Alzheimer's Disease (AD) individuals. J Neuroimmunol 1999; 97 (1-2): 163-171.
40. Speciale L, Calabrese E, Saresella M, Tinelli C, Mariani C, Sanvito L, Longhi R, Ferrante P. Lymphocyte subset patterns and cytokine production in Alzheimer's disease patients. Neurobiol Aging 2007; 28 (8): 1163-1169.

41. Shalit F, Sredni B, Stern L, Kott E, Huberman M. Elevated interleukin-6 secretion levels by mononuclear cells of Alzheimer's patients. Neurosci Lett 1994; 174 (2): 130-132.

42. Fiala M, Lin J, Ringman J, Kermani-Arab V, Tsao G, Patel A, Lossinsky AS, Graves MC, Gustavson A, Sayre J, Sofroni E, Suarez T, Chiappelli F, Bernard G. Ineffective phagocytosis of amyloid-beta by macrophages of Alzheimer's disease patients. J Alzheimers Dis 2005; 7 (3): 221-232.

43. Chou JP, Effros RB. T cell replicative senescence in human aging. Curr Pharm Des 2013; 19: 1680-1698.

44. Goodwin K, Viboud C, Simonsen L. Antibody response to influenza vaccination in the elderly: a quantitative review. Vaccine 2006; 24 : 1159-1169.

45. Goronzy JJ, Fulbright JW, Crowson CS, Poland GA, O'Fallon WM, Weyand CM. Value of immunological markers in predicting responsiveness to influenza vaccination in elderly individuals. J Virol 2001; 75: 12182-12187.

46. Saurwein-Teissl M, Lung TL, Marx F, Gschösser C, Asch E, Blasko I, Parson W, Böck G, Schönitzer D, Trannoy E, Grubeck-Loebenstein B. Lack of antibody production following immunization in old age: association with CD8 (+)CD28 (-) T cell clonal expansions and an imbalance in the production of Th1 and Th2 cytokines. J Immunol 2002; 168: 5893-5899.

47. Trzonkowski P, Mysliwska J, Szmit E, Wieckiewicz J, Lukaszuk K, Brydak LB, Machala M, Mysliwski A. Association between cytomegalovirus infection, enhanced proinflammatory response and low level of anti-hemagglutinins during the anti-influenza vaccination - an impact of immunosenescence. Vaccine 2003; 21: 3826-3836.

48. Novak P, Schmidt R, Kontsekova E, Zilka N, Kovacech B, Skrabana $R$, Vince-Kazmerova Z, Katina S, Fialova L, Prcina M, Parrak V, Dal-Bianco P, Brunner M, Staffen W, Rainer M, Ondrus M, Ropele S, Smisek M, Sivak R, Winblad B, Novak M. Safety and immunogenicity of the tau vaccine AADvac1 in patients with Alzheimer's disease: a randomised, double-blind, placebo-controlled, phase 1 trial. Lancet Neurol 2017; 16 (2): 123-134.

49. Kontsekova E, Zilka N, Kovacech B, Novak P, Novak M. First-inman tau vaccine targeting structural determinants essential for pathological tau-tau interaction reduces tau oligomerisation and neurofibrillary degeneration in an Alzheimer's disease model. Alzheimers Res Ther 2014; 6 (4): 44. 